\title{
Vietnamese Language in Westernization: Integration or Disguise?
}

\author{
Le Khac Cuong 8 (D) \\ Vice President, Hong Bang International University Ho Chi Minh City, Vietnam \\ $\triangle$ Corresponding Author: Le Khac Cuong, E-mail: cuonglk@hiu.vn
}

\author{
ARTICLE INFORMATION \\ Received: August 14, 2021 \\ Accepted: September 29, 2021 \\ Volume: 1 \\ Issue: 2 \\ DOI: $10.32996 /$ ijls.2021.1.2.3
}

\section{KEYWORDS}

Vietnamese, language, integrity, preservation, integration

\section{ABSTRACT}

Through proud historical development, the Vietnamese language has overcome all obstacles to become a rich and beautiful language, with a unique identity and full of potential. In the international arena, in all fields of activities, Vietnamese has equal status with all other languages. The process of integration and development will inevitably entail contact and mutual influence between cultures, including languages. On the positive side, it has contributed to enriching the lexicology of the national language, especially new terminologies in the fields of science and technology, make more diverse forms of communication, and in some ways, it shortens the gaps to more developed cultures and civilizations. However, in terms of culture, it can also cause negative effects, that is, chaos, tension in Vietnamese disguise. This paper reports the current status of the Vietnamese language in the midst of Western trends in Vietnam. Data were collected from historical documents and daily news from popular sites of Vietnamese mass media.

\section{Introduction}

The language of each country is an invaluable asset (Fishman, 1972; Blommaert, 1996). Language is an element of national cultural identity (Tabouret-Keller, 2017; Jiang, 2000; Kramsch, 1998; Hoijer, 1954). The Vietnamese people have their language. That language has long been a unified national language, basically stable in terms of phonetics, vocabulary, and grammar. Along with the rapid development of science and technology and the influence of the globalization process, the Vietnamese language has changed significantly. Besides the positive factors that are worth noting, there are still several complicating problems that can damage the clarity of the Vietnamese language. The tendency to use the Vietnamese language arbitrarily, disrespectfully, and sometimes the excessive creativity that distorts the Vietnamese language is rather common (Gia Khanh, 2020; Nguyen, 2019). In the current social context in Vietnam, when the people's intellectual level has been improved, and the integration with the world is happening every day, the question is: How to preserve the clarity of the Vietnamese language? It can be said that nowadays, not only on social networks, in the communication of young people, in the activities of a part of society, but also in some newspapers, the phenomenon of foreign language abuse due to Westernization is becoming more and more noticeable. Whatever the reason, this phenomenon affects the clarity of the Vietnamese language (Phan, 2018).

Clause 3, Article 5 of the 2013 Constitution clearly states: "3. The national language is Vietnamese. Ethnic groups have the right to use their language and script, preserve their national identity, and promote their fine customs, practices, traditions, and culture". Over the past time, the Vietnamese language has become richer and richer, plays an important role in all aspects of life, is the main communication instrument, contributes to exchange and learning, transmits knowledge, literary works... There is an increase in the tendency to overuse foreign languages. That trend does not have any signs of stopping. Therefore, the phenomenon of the Vietnamese language being distorted and stretched has raised several issues that need to be seriously considered and properly guided (Vu, 2018; Phuong Anh, 2018; Nguyen, 2013).

The reason is that a large part of Vietnamese people, especially young people, are influenced by the trend of Westernization and modernization. They are lacking in knowledge of the Vietnamese language, not clearly defined, or even irresponsible in protecting the Vietnamese language. In addition, media programs and social networking sites are inadvertently aiding in the destruction of

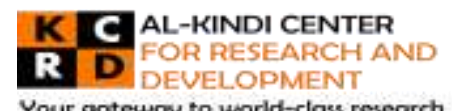

Your goteway to world-class research

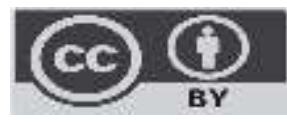

Published by Al-Kindi Center for Research and Development. Copyright (c) the author(s). This open access article is distributed under a Creative Commons Attribution (CC-BY) 4.0 license 
the Vietnamese language, making this process happen faster. Meanwhile, society's views on these new trends are still inefficient and unclear, not to mention numerous conflicting perspectives, causing solid obstacles in standardizing the use of the Vietnamese language.

\section{Backgrounds of Vietnamese language}

Most languages in the world have borrowed and imported words from outside. The reason is a language inherently does not have enough vocabulary to define all the concepts. Furthermore, it is also an inevitable trend in the process of cultural integration. Vietnamese is no exception to that rule. Vietnamese has lots of Sino-Vietnamese words as well as French loanwords (Alves 2018; Taylor, 2013; Shu-guan, 2012; Alves, 2008). According to statistics, 60\% of Vietnamese words are from Chinese (Nguyen, 2018). However, when put into use, they have been Vietnameseized to suit the phonetic system of the Vietnamese language $(T e, 1987)$. This system has been used since the X-XI centuries (Baker, 1969). Not only that but Vietnamese also uses elements of Chinese origin to create new words only used in Vietnamese, for example, tiểu đoàn, binh lính, tàu thủy.

Due to historical characteristics, a large number of words currently used in the Vietnamese language treasure are borrowed from France (Baker, 1969; Te, 1987; Nguyen, 2018). Most of this word range is the name of objects from the French penetrated, which usually did not exist in Vietnamese at that time. Therefore, those words have been changed in both reading and writing to match the characteristics of the Vietnamese language (Le Khac, 2014). French loan words are used in several areas such as: café (cà phê), crème (kem), carotte (cà rốt), gâteau (ga tô), salade (xa lát), cerise (sơ ri), fromage (pho mát), jambon (giăm bông), pénicillin (pênixillin), vaccine (vắc xin), vitamine (vitamin), etc. and many other fields. These word classes have gradually been accepted in the Vietnamese vocabulary and are used appropriately by Vietnamese people in communication contexts (Le Khac, 2014).

\section{Current status of Vietnamese language}

Cultural and social interference requires language changes to meet new communication needs. Along with the exchange and integration, the Vietnamese language also gradually appeared a new phenomenon. New words and expressions were formed to add concepts, even structures and styles that were lacking in Vietnamese before, such as in the field of information technology, digital, etc. production and business of the market economy... Along with that positive side, many negative phenomena also penetrated with different ways of speaking and writing. Recent studies, as well as daily observations, show a serious decline, distorting the Vietnamese language, which is extremely rich, diverse, and clear. From daily conversations, the chatting language on the Internet, text messages on the phone, etc., a large number of young people today are creating a new style of language for their identities. They freely abuse slang, borrow foreign words, even reluctantly combine to build words and phrases that make the Vietnamese language ominous.

\section{1 The variation of Vietnamese in music}

Not only do young Vietnamese people like to speak foreign languages, or sometimes add a few words of English to their daily communication, there is also the phenomenon of composing songs using foreign lyrics partially by young musicians. If it is a Vietnamese song with lyrics translated into a foreign language, it is very encouraging, helping the song reach the masses, especially when it is posted online, reaching foreigners. However, this is a song whose lyrics sometimes include a few words or sentences in a foreign language, making the audience feel awkward and sometimes uncomfortable.

For example, the song "Nụ hôn bất ngờ" (Sudden Kiss) has the passage: "Bóng trăng đã tàn rồi về khuya dường như muốn nói: "Ta về thôi". Thế sao vẫn ngồi, anh nhe nhàng hôn lên mắt môi. Thật nồng say, một nụ hôn tựa như mây. Oh first kiss! You make me happy! You make me crazy! Rồi em mới hay thì ra có người thương nhớ thầm em bấy lâu". In addition, the song "Please tell me why" has these sentences: "Please tell me why? Sao em ra đi không một lời nói? Please tell me why? Con tim anh không sao quên được người Baby. Please tell me why? Cho anh hay sao em lại đành nói lời chia tay khi biết anh vẫn luôn luôn thật lòng yêu em. Và thầm chờ mong em trở về Baby. My baby love you so much forever you and I". Another proof is the song "Tình về nơi đâu" (Where does love go?). It has the part: "Where do we go (Tình minh về đâu hỡi em)? Are we ready to just give it up? Should we turn our back on love. Or should we stand within? Chẳng đành lòng buông cánh tay. Chi mình anh sao biết quay lại. Ngày nào say đắm vô vàn. Sao minh xa cách nhau? Where do we go (người oii)? Where do we go (em hỡi)? Where do we go (về đâu)? Yêu thương cho tới nơi đâu". Vietnamese is a language rich in images, rich in melody, with high expressive ability, so musicians do not need to borrow from English language to add in the lyrics.

\subsection{The transformation of Vietnamese in the mass media}

The phenomenon of English words being mixed with Vietnamese is very common, currently, in the mass media, even though there are Vietnamese words with equivalent meanings. On TV game shows and news programs, numerous English words are commonly used such as "Start-up" while Vietnamese already has the word "Khởi nghiệp"; "diva"_ "nũ danh ca" in Vietnamese. Even familiar communication words like "cám ơn" or "xin lỗi" are also replaced by English words "thank you" and "sorry". This phenomenon can be seen on the Facebook page of many celebrities with the statuses written half in English and half in Vietnamese: "Thanks mọi 
người."; "Hôm nay sẽ chính thức on-air"; "Tối qua dự event với team, hôm nay tiếp tục shooting cả ngày"... The above sentences can be expressed in pure Vietnamese words, which are clear and easy to understand. For example, "cảm ơn" instead of "thanks"; "sự kiện" for "event"; "lên sóng" for "on-air"; "đội" for "team" and "chụp ảnh" for "shooting". This style of writing affects a part of the population, especially young people, making them imitate those celebrities, thinking that it is trendy and stylish. This is one of the reasons for the emerging trend of using foreign languages to replace Vietnamese words.

In addition, although Vietnamese still has equivalent lexicology to reflect the content mentioned, Vietnamese young people and the press prefer to use foreign words. For example, showbiz (giới giải trí), top (đứng đầu), shock (sốc), scandal (vụ bê bối), stress (căng thăng), or game show (truyền hình thực tế). The media needs to pay attention to the standards in journalistic language, help the public understand the message, and contribute to the preservation of the clarity of the Vietnamese language. The language used in the mass media is not a puzzle, even less a place to show the style (Lam, 2020).

\subsection{The transformation of Vietnamese in the Vietnamese language itself}

In Vietnamese, modified proverbs or anti-proverbs are more and more popular among young people and on the Internet (Tran, 2012). Anti-proverbs (the phenomenon of speakers using structures, words, ideas, etc. of existing idioms and proverbs, adapting them to be used in everyday life for humour or sarcasm and irony) is a phenomenon that has been recorded for a long time in English and has now become popular in Vietnamese. According to Vu (2008: 39), a proverb is " $a$ sentence that fully expresses an idea, a comment, an experience, a moral, sometimes a criticism" which is widely used among people with a stable structure, complete meaning, and a genre of folklore culture". For example, "Một giọt máu đào hơn ao nước lãa", "Có chí thì nên". Proverbs are often used to give advice, draw experience, and help sentences or words to be condensed and concise. Anti-proverbs were introduced by Wolfgang Mieder and Lutz Rohrich (1977) to refer to the manipulation, parody, distortion, or variation of the original proverbs. An anti-proverb can have a similar form or content to which a proverb originates. For example, "Time wounds all heels" from "Time heals all wounds".

Some popular Vietnamese anti-proverbs are: "Có chí thì nên... cạo đầu", "Một điều nhịn là chín điều nhục", "Đã xấu mà lại còn xa, đã siđa lại còn xông pha hiến máu", "Không mày đố thầy dạy ai", "Chết vì tình là cái chết bất thình lình". These non sense proverbs even appear on printed T-shirts, and television advertisment: "Một ly làm chẳng bao nhiêu, ba ly chụm lại nên tầm vóc cao". The movie "Hạnh phúc bất ngờ" on HTVC Family channel (2011) also has the sentence "Sống trên đời không ăn thịt chó, chết xuống tuyền đài không có dồi chó mà ăn" (Tran, 2013). When anti-proverbs appear in high frequency, it raises concerns about preserving the purity of the Vietnamese language.

\section{Recommendations}

It is undeniable that foreign languages have been playing crucial roles, but the national language in Vietnam, Vietnamese, is still the priority. Therefore, first of all, it is necessary to actively accept the trend of modernization without losing the original identity of the national language. On the one hand, Vietnamese people welcome new things, but they must be critical and selective. Second, they should use foreign languages only in mandatory cases, do not mix languages when unnecessary, as well as avoid Vietnameseizing all words in a forced and respectful manner. The current situation requires timely intervention, guidance, and correction of all levels and sectors. Third, for each family, it is necessary to create a healthy language environment, and shape the use of mother tongue for children from an early age. Teachers and schools must set an example in using language when carrying out the process of educating children. They continue to shape, orient and nurture children to perfect their Vietnamese vocabulary. With the mass media, in addition to being careful in using words, it is also necessary to strengthen practical content, which greatly contributes to the language cultivation of many people, especially young ones. State management agencies need to have resolute measures and specific sanctions in the management of this field. Preserving the purity of the Vietnamese language is also a requirement of Deputy Prime Minister Vu Duc Dam raised in 2019.

\section{Conclusion}

In conclusion, this paper has just reported the current status of the Vietnamese language in the midst of Western trends in Vietnam. The findings show that the overuse of foreign words in Vietnam is significant but not necessary. These findings are supported by many authors (Gia Khanh, 2020; Lam, 2020, Nguyen, 2019; Le Khac 2014 ). In addition, this research has pointed out that in some cases, this trend breaks the purity of the Vietnamese language. The limitation of this paper is the small number of documents and pieces of news. Therefore, the future study can expand this scope.

Nowadays, when the trend of integration and internationalization is becoming stronger and stronger, learning a foreign language is necessary. Knowing a foreign language is like opening another door of culture, but using a foreign language needs to adhere to certain rules and cannot be arbitrary. With the requirements of the new working environment, each individual cannot limit himself to the national language. They need to equip themselves with other languages. Learning a foreign language is not only a requirement but also an important means of creating good opportunities for them to develop their abilities. Foreign languages 
(especially international languages) have become a bridge, a catalyst for all modern societies, but they cannot replace the national language. Each nation and ethnic group, including Vietnam, must know how to preserve and respect their language. It is also an effective way for every ethnic group to deal with the risk of being dissolved and losing their cultural identities in the integration period.

\section{References}

[1] Alves, M. (2006). Linguistic research on the origins of the Vietnamese language: An overview. Journal of Vietnamese Studies, 1(1-2), 104-130.

[2] Alves, M. J. (2008). Sino-Vietnamese grammatical borrowing: An overview. Cross-Linguistic Perspective, 343-362.

[3] Alves, M. J. (2018). Early Sino-Vietnamese Lexical Data and the Relative Chronology of Tonogenesis in Chinese and Vietnamese. Bulletin of Chinese Linguistics, 11(1-2), 3-33.

[4] Barker, M. E. (1969). The phonological adaptation of French loanwords to Vietnamese. Mon-Khmer Studies Journal, 3, $138-147$.

[5] Blommaert, J. (1996). Language and Nationalism: comparing Flanders and Tanzania. Nations and Nationalism, 2(2), 235-256.

[6] Fishman, J. A. (1972). Language and Nationalism: Two Integrative Essays.

[7] Gia K. 2020. https://www.qdnd.vn/ban-doc/thu-ban-doc/giu-gin-su-trong-sang-cua-tieng-viet-tren-mang-xa-hoi-634247 [assessed on August $\left.25^{\text {th }}, 2021\right]$

[8] Hoijer, H. E. (1954). Language in culture; Conference on the Interrelations of Language and Other Aspects of Culture.

[9] Jiang, W. (2000). The relationship between culture and language. ELT Journal, 54(4), 328-334.

[10] Kramsch, C. (1998). Language and culture. Oxford University Press.

[11] Le Ha, P., Ha, V. H., \& Dat, B. (2014). Language policies in modern-day Vietnam: Changes, challenges, and complexities. In Language, Education, and Nation-Building (pp. 232-244). Palgrave Macmillan, London.

[12] Le K. C. 2014. https://petrotimes.vn/pgsts-le-khac-cuong-can-giu-gin-tieng-viet-159293.html [assessed on August 25 th , 2021]

[13] Lam. 2020. https://vnexpress.net/cho-tre-hoc-tieng-anh-qua-som-4092659.html [assessed on August 25 $\left.{ }^{\text {th }}, 2021\right]$

[14] Marginson, S., Trần, L. T., \& Đỗ, H. M. (2014). Modernization with Vietnamese characteristics. In Higher Education in Vietnam (pp. 229-236). Palgrave Macmillan, London.

[15] Nguyen D. 2013. https://nhandan.vn/dien-dan/chan-chinh-quang-cao-bien-hieu-tieng-nuoc-ngoai-180975/ [assessed on August 25 ${ }^{\text {th }}$, 2021]

[16] Nguyen, L. (2018). Borrowing or Code-switching? Traces of community norms in Vietnamese- English speech. Australian Journal of Linguistics, 38(4), 443-466.

[17] Nguyen, T. D. (2018). Studies on Vietnamese Language and Literature. Cornell University Press.

[18] Nguyen V. H. 2019. https://tuyengiao.vn/nghien-cuu/ly-luan/trach-nhiem-bao-chi-trong-viec-giu-gin-su-trong-sang-cua-tieng-viet-120924 [assessed on August 25 $5^{\text {th }}, 2021$ ]

[19] Phan, H. L. (2000). Suy nghĩ nhỏ về một vấn đề lớn: vấn đề giữ gìn sự trong sáng của tiếng Việt. [assessed on August 25 $5^{\text {th }}$,2021]

[20] Phan N. 2018. https://tuoitre.vn/co-tro-cung-giu-su-trong-sang-cua-tieng-viet-20180109083803597.htm [assessed on August 25th 2021 ]

[21] Phuong A. 2018. http://daibieunhandankhanhhoa.gov.vn/?Articleld=594aacbd-8a23-46d9-a2f3-f7075073c954 [assessed on August 25 ${ }^{\text {th }}$, 2021]

[22] Tabouret-Keller, A. (2017). Language and identity. The handbook of sociolinguistics, 315-326.

[23] Taylor, K. W. (2013). A History of the Vietnamese. Cambridge University Press.

[24] Te, H. D. (1987). Introduction to Vietnamese Culture. Multifunctional Resource Center.

[25] Tran, T. L. N. 2012. Phan tuc ngu hay la su van dung sang tao tuc ngu trong tieng Anhva tieng Viet. Tap Chi Khoa Hoc Van Nghe , Dai hoc Da Nang. 1(50), 189-195.

[26] Truong, L. B., \& Tran, L. T. (2014). Students' intercultural development through language learning in Vietnamese tertiary education: A case study on the use of film as an innovative approach. Language and Intercultural Communication, 14(2), 207-225.

[27] Vu V. T. 2018. https://tuoitre.vn/chan-chinh-loan-bien-hieu-tieng-nuoc-ngoai-tai-nha-trang-2018040615260699.htm [assessed on August $\left.25^{\text {th }}, 2021\right]$ 